lows-who then would thank to join such a "motley crew." Let no man affect indignation, and consider such a remark a mere insult to our common profession. He knows as well as I know; that there are many members of the College of Surgeons, who do not 80 conduct themselves as to maintain the character of gentlemen, nor consequently of surgeons. Why should such be made Fellows of the College? Why should any man, for the future, be made a Fellow, save and except from merit, as tested in some way; whether exclusively by examination; or by examination, or the suffrages of a given number of the profession in favour of a member of a certain standing ? It is highly absurd for grumblers to assert that they have been unjustly orerlooked, that they are quite equal to the best amongst the more fortunate. They may be $10 ;-$ mapy probably are. But the world always acts upon confirmed knowledge, or what is supposed to be such; and it matters little that X. Y. Z. is a cleverer man, and more skilful surgeon than Brodie or Lawrence, unless the world knows it.

Being a member of the College, I am injured as much as any other member is, by not being elected a Fellow; still were $I$ to be made a Fellow in common with all the other members of the College, I should esteem the Fellowship merely as a dead letter. I therefore sincerely hope that Sir James Graham and the College of Surgeons will not extend the Fellowship, but ensure that every future possessor of it shall have proved himself in some way deserving of distinction. The Fellowship is either an honour, or it is nothing If intended to be the former, it must not be made too cheap.

In these sentiments I am not alone, though others may be more hesitating in the expression of them.

I enclose my name and address,

And remain, Sir,

Your obedient serrant,

August 9, 1845. CHIRURGUS.

\section{THE PROVINCIAL MEDICAL AND SURGICAL ASSOCIATION.}

One of the subjects of discussion at the late anniversary meeting of the Provincial Medical and Surgical Association, at Sheffield, related to the continuance or discontinuance of the Provincial Medical and Surgical Journal. There was some difference of opinion on the subject; and finally a resolution, proposed by Dr. Hastings, was carried, that the Journal should be continued, but diminished in size. We are pleased to find that we shall not lose our cotemporary altogether. This Journal has long formed a channel for the communications of provincial practitioners, on facts connected with practical medicine and surgery, and we have frequently made use of these contributions in an abridged form. We think that many interesting cases would remain entirely nnknown to the profession; but for the publicity which they obtain through a Journal of this description. We can understand that men. who might, from indolence or indifference, hesitate to write for the older periodicals, would feel that a strong necessity existed for giving their literary support to Journal in the success of which they had a common interest. On this account we should regret its discontinuance. The Journal may not centain so much matter as some of its cotemporaries, but it is less infected with politics and personalities, and we hope long to see it continue its quiet and eren course.-London Medical Gazette, August 15th.

\section{ROYAL COLLEGE OF SURGEONS.}

Gentlemen admitted Members, on Monday, August 11th, 1845 :-H. M. Cockerton; T. Eccleston; T. E. Eden; T. S. Tate; S. H. Fasson; E. Martin ; T. Peppard; H. McCarthy ; J. Wallace ; J. Bayly ; W. H. Wright ; G. F. Hodgson; J. Maund.

Friday, Aug. 15th :-E. Waters; F. Collins.

\section{SOCIETY OF APOTHECARIES.}

Gentlemen admitted Licentiates, Thursday, Auguat 7, 1845 :-G. Allen, London; H. Bailey, Artsey; J. Clay, Birmingham; J. Clement, Gateshead; W. Lightfoot, Cowley; M. Anthony.

Thursday, August 14th:-R. Ripley, Whitby ; J. Spurr, Wigthorpe; T. Frederic, Grimsdale; J. Terry, Batheastou.

\section{OBITUARY.}

It is with regret that we announce the death of $\mathrm{Dr}$. E. Octavius Hocken, of London, which took place on the 12th instant, from tubercular phthisis; a disease which formed the subject of one of his latest publications. As a writer, D.. Hocken is somewhat exten. sively known from his published works, as well as bis numerous contributions to the various periodicals; and of them, his carefully prepared work on amaurosis, and elaborate article on retinitis, in the last rolume of the Transactions, redound greatly to his credit. Withunt possessing much claim to originality, he was a most industricus and hard.working young man, and his decease at sucls an early age must be a matter of sincere regret to all.

\section{BOOKS RECEIVED.}

A Practical Treatise on Inflammation, Ulceration, and Induration of the Neck of the Uterus; with Remarks on the value Lencorrhœa and Prolapsns Uteri as Symptoms of Uterine Disease. By James Henry Bennet, M.D., Licentiate of the Royal College of Physiciaus, \&c. London : Churchill. 1845. 8ro. pp. 212. The Pharmaceutical I atin Grammar; being an Easy Introduction to Medical Latin, the London Pharmacopceia, and the perusal of Physicians' Prescriptions. By Arnold James Cooley, \&c. London : Groombridge. 1845. pp. 132.

A Second Report by the Deputation of General Practitioners.

\section{ERRATUM.}

At p. 518, col. 2, line 12, for " raised," read " roused."

TO CORRESPONDFNTS.

Communications have been received from $\mathrm{Mr}$. G. Southam; the Birmingham Pathological Society; Dr. P. H. Williams; Mr. J. Harmar Smith; Mr. F. Cox; Mr. H. Jackson; a Medical Coroner; Mr. W. Allison; and Dr. H. Jobnson. 